\section{(6) OPEN ACCESS}

Department for Health, University of Bath, Bath, UK

\section{Correspondence to}

Dr Gary Fooks, Department for Health, University of Bath,

Bath BA2 7AY, UK

g.fooks@bath.ac.uk

Received 30 October 2012 Accepted 25 April 2013 Published Online First 20 June 2013

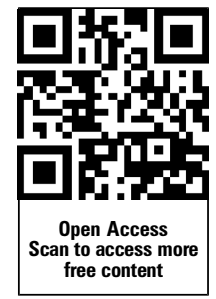

To cite: Fooks $G$, Gilmore AB. Tob Control 2014;23:e1.

\title{
International trade law, plain packaging and tobacco industry political activity: the Trans-Pacific Partnership
}

\author{
Gary Fooks, Anna B Gilmore
}

\section{ABSTRACT}

Tobacco companies are increasingly turning to trade and investment agreements to challenge measures aimed at reducing tobacco use. This study examines their efforts to influence the Trans-Pacific Partnership (TPP), a major trade and investment agreement which may eventually cover $40 \%$ of the world's population; focusing on how these efforts might enhance the industry's power to challenge the introduction of plain packaging. Specifically, the paper discusses the implications for public health regulation of Philip Morris International's interest in using the TPP to: shape the bureaucratic structures and decision-making processes of business regulation at the national level; introduce a higher standard of protection for trademarks than is currently provided under the Agreement on Trade Related Aspects of Intellectual Property Rights; and expand the coverage of Investor-State Dispute Settlement which empowers corporations to litigate directly against governments where they are deemed to be in breach of investment agreements. The large number of countries involved in the TPP underlines its risk to the development of tobacco regulation globally.

\section{INTRODUCTION}

International trade and investment law is constituted by bilateral, regional/plurilateral (regional) and multinational agreements (box 1) which create legal obligations between parties and specify fora for the resolution of disputes between them. The tobacco industry has a long history of using trade agreements to expand into new markets. ${ }^{1-7}$ Recent evidence suggests that major tobacco companies are increasingly turning to trade and investment agreements to challenge measures aimed at reducing tobacco use. ${ }^{8-11}$ Current industry efforts in this area centre on policies designed to reduce the effects of pack branding on consumer demand (such as generic packaging and large pictorial warnings) and take three broad forms: support for national governments' complaints to the World Trade Organisation (WTO) (box 1); ${ }^{12}$ direct legal action against national governments using Investor-State Dispute Settlement (ISDS) under trade and investment agreements ${ }^{11}{ }^{13-16}$ (box 1); and lobbying national governments to shape the terms of new international agreements so as to extend the coverage of ISDS and generally strengthen tobacco companies' capacity to challenge public health policy. ${ }^{11}{ }^{16}{ }^{17}$ This paper focuses on the last of these and specifically on Philip Morris International's (PMI) efforts to shape the Trans-Pacific Partnership (TPP). In doing so it aims to examine the implications of the TPP for plain packaging legislation.

\section{BACKGROUND}

The TPP

The TPP has its origins in a proposal made by the USA in 1998 to Australia, Chile, New Zealand and Singapore for a free trade agreement which would encourage other Asia Pacific Economic Cooperation (APEC) members to liberalise their trade. ${ }^{18}$ The initiative led to the Trans-Pacific Strategic Economic Partnership Agreement which contained an accession clause permitting other countries to join and create the basis for a larger agreement covering the entire APEC region. ${ }^{18-20}$ In 2007, negotiations began for the TPP, a significantly expanded version of the agreement, encompassing a larger group of countries. ${ }^{19}$ Negotiating states currently include the USA, Australia, New Zealand, Chile, Peru, Singapore, Malaysia, Vietnam, Brunei, Canada and Mexico. ${ }^{17} 2122$ Their aim is to produce an agreement that other countries in the APEC grouping will adopt, creating a Free Trade Area of the Asia Pacific which the United States Trade Representative (USTR) hopes will eventually cover $40 \%$ of the world's population. ${ }^{23}$ In November 2012, Thailand became the latest state to formally express an interest in joining. ${ }^{24}$

Described by its critics as a bill of rights for large corporations, which fundamentally shifts the balance of power between business and government, the TPP follows other investment treaties in extending protection to a wide range of proprietary interests, including contract rights, intellectual property (IP) and market share. ${ }^{10-30}$ Negotiations have been conducted almost entirely in secret. A decision to keep negotiating texts confidential until 4 years after a deal is completed has opened up the process to criticism that it is effectively allowing negotiators to rewrite domestic regulation without democratic scrutiny. ${ }^{31}$ The fact that representatives of corporations in the USA serve as official advisers, have full access to draft texts of the agreement, and a special role in negotiations has reinforced concerns that the final draft of the agreement will radically extend corporate property rights. ${ }^{31}$

\section{PMI's interest in and efforts to shape the TPP}

While there is some evidence to suggest that other big tobacco companies have been using the anonymity provided by industry associations to influence the $\mathrm{TPP}^{32}$ PMI's objectives for the agreement are publicly accessible. In its 2010 response to a US Federal Register notice, ${ }^{33}$ the company called for three main proposals: 'harmonization of legitimate, science-based regulations', an investor-state dispute mechanism, and a comprehensive 'Trade Related Aspects of Intellectual Property Rights (TRIPS)-plus' IP chapter comprising 'a high standard of protection for 


\section{Trade and Investment Law}

The key institution in the governance of international trade and investment is the World Trade Organisation (WTO). The organisation oversees a large number of multinational agreements which member countries must ratify on accession, ${ }^{133}$ and, unusually for a trade and investment regime, has its own standing body to settle disputes (see box ${ }^{3}$ and below in the main text). The Organisation operates alongside a large number of bilateral and regional agreements. Bilateral investment treaties (BITs) are more significant in quantitative terms (estimated at 2833 at the beginning of 2012). However, the annual number of new bilateral agreements is in decline, while efforts to develop and extend regional agreements, such as the Trans-Pacific Partnership (TPP), are intensifying. ${ }^{54} 134$

A number of factors work to harmonise the protection of foreign investments by creating overlaps and structural interconnections between agreements. Most-favoured-nations (MFN) provisions in bilateral and regional agreements grant investors rights to more favourable legal protections or entitlements in other investment agreements. ${ }^{11}$ An investor covered by an agreement with a MFN clause can therefore invoke the benefits granted to third-party nationals by another agreement of the host state and import them into its relationship with the host State. ${ }^{135}$ Furthermore, some agreements, such as the BIT between Hong Kong and Australia (Hong Kong-Australia BIT), require parties to observe any other obligations they may have entered into which may potentially extend to general obligations in international treaties (such as TRIPS). ${ }^{11}$ Finally, many states base agreements on model investment treaties that provide a core set of protections such as expropriation and compensation (which encompass measures that diminish or interfere with property rights) and fair and equitable treatment (which can cover the failure to respect an investor's legitimate expectations, arbitrary, discriminatory or unreasonable treatment, and denial of procedural fairness)..$^{11} 16136137$

Tobacco Industry's use of Trade and Investment Law against Regulations affecting Pack Branding

Australia's Tobacco Plain Packaging Act 2011 and implementing regulations (the 2011 Act) are subject to a complaint in the WTO and a notice of claim from Philip Morris Asia (PM Asia) under the BIT between Hong Kong and Australia. ${ }^{69} 70$ 138-141

The complaint in the WTO, initiated by Ukraine, underlines the importance of three WTO agreements to plain packaging-the General Agreement on Tariffs and Trade (GATT), the Agreement on Trade Related Aspects of Intellectual Property Rights (TRIPS), and the Agreement on Technical Barriers to Trade. ${ }^{138-141}$ In the context of the present paper, it should be noted that the USA is making efforts to strengthen Technical Barriers to Trade standards and intellectual property (IP) protection under the TPP. ${ }^{42}$

Among other things, PM Asia's complaint under the Hong Kong-Australia BIT claims that the 2011 Act represents an expropriation of its IP and violation of its rights under the Treaty to fair and equitable treatment (see below in the main text). ${ }^{70} \mathrm{PM}$ Asia are also claiming that the 2011 Act breaches Australia's international obligations by violating TRIPS, the Paris Convention for the Protection of Industrial Property and the WTO Agreement on Technical Barriers to Trade. ${ }^{42}$

In addition to the above, a subsidiary of Philip Morris International (PMI) has filed a request for arbitration against Uruguay alleging that a requirement that tobacco packages include graphic images of the health consequences of smoking, a mandate that health warnings cover $80 \%$ of the front and back of cigarette packages, and a single presentation requirement (which prohibits marketing of more than one tobacco product under each brand) violate several provisions of the Switzerland-Uruguay BIT. ${ }^{14} 142$ Porterfield and Byrnes note that PMI are asserting an expansive interpretation of fair and equitable treatment, including a right to a 'stable and predictable regulatory framework. ${ }^{\prime 143}$ The request for arbitration also alleges that the single presentation requirement constitutes an expropriation of Philip Morris's trademarks by prohibiting their use on multiple brands.

trademarks. ${ }^{33}$ Each of these requests is reflected in subsequent leaked draft texts of the TPP agreement. ${ }^{34-36}$

The following analysis is divided into four substantive sections. The first three examine how each of PMI's three proposals is likely to strengthen the tobacco industry's capacity to prevent the introduction of plain packaging. The fourth briefly examines the extent to which a tobacco-specific exception announced by the USTR, but not yet formally proposed, might nullify the effect of these proposals.

\section{'HARMONIZATION OF LEGITIMATE, SCIENCE-BASED REGULATIONS': BETTER REGULATION, POLITICAL ACCESS AND INFORMATION LEVERAGE}

Leaked text of a draft TPP chapter on 'regulatory coherence' suggests that negotiating parties are seeking to use the TPP to stipulate guidelines for regulatory rulemaking and review along the lines of the Better Regulation and regulatory review agenda in the European Union (EU) and USA. ${ }^{37} 38$ This represents a departure from existing investment agreements and is part of a global process of regulatory reform that draws heavily on US administrative law and its cost-benefit approach to regulatory review. $^{23} 39-41$ The formal purpose of the chapter is to establish rules for regulatory formation and review that will reduce the likelihood of TPP countries creating and maintaining regulations that are inconsistent with the agreement. ${ }^{42}$ Some of the guidelines proposed are consistent with well-informed, methodical decision-making. ${ }^{41}$ However, they also promise to increase tobacco companies' capacity to influence health policy by increasing their access to the policymaking process, augmenting their ability to challenge regulation and reinforcing their existing information advantage. ${ }^{23} 3543-48$

Three provisions in the draft chapter are likely to facilitate tobacco companies' policy access. The first is a recommendation that parties to the TPP establish a national coordinating body with the power to review whether regulatory measures adhere to 'good regulatory practices'. ${ }^{35} 49$ A similar system of review is practiced by the Australian Office of Best Practice Regulation, a regulatory oversight body in Australia which monitors how government departments and agencies develop regulation. ${ }^{50}$ In 2010, the office concluded that a draft regulatory impact assessment prepared by the Department of Health and Ageing for the Australian plain packaging law did not satisfy best practice guidelines. The policy was subsequently adjudged 'noncompliant' and earmarked for a postimplementation review within 2 years of it taking effect. ${ }^{23} 51$ Reviews such as this provide tobacco companies with increased opportunities to 
challenge and shape regulation. ${ }^{23}$ In the case of the TPP, which recommends that existing, as well as new, regulation is regularly appraised, these opportunities are likely to be substantial. ${ }^{49}$ The second, a recommendation that the national coordinating body ensures that all ministries with an interest in a particular regulation participate in its development, is likely to increase involvement of non-health ministries who are more likely to promote tobacco industry interests. ${ }^{52}$ The third provision is a recommendation for collaboration between governments and 'their respective stakeholders', including dialogue, meetings and exchange of information. ${ }^{35}{ }^{49}$ British American Tobacco played a key role in a broad alliance of multinational corporations promoting a similar requirement for stakeholder consultation in EU policymaking and the tobacco industry has subsequently used such requirements in its efforts to undermine Article 5.3 of the WHO Framework Convention on Tobacco Control which, among other things, seeks to reduce tobacco industry access to policymakers. ${ }^{37} 53$

A recommendation in the draft to integrate impact assessments into policy may also enhance tobacco companies' influence over policymaking. Existing research on British American Tobacco's efforts to embed impact assessments into the policymaking processes of the EU indicates that their primary aim was to formalise their ability to exploit information asymmetries that commonly characterise business-government relations. ${ }^{37} 3841$ Finally, the draft chapter also proposes that governments ensure their regulatory bodies provide access to 'supporting documentation' relating to regulatory measures, analyses and data. Such detailed disclosure exacerbates existing information asymmetries between business and government, thereby increasing the industry's leverage to challenge decision-making. ${ }^{23}$

\section{INVESTOR-STATE DISPUTE SETTLEMENT}

Increasing numbers of bilateral and regional agreements have included dispute settlement clauses permitting investors (typically, although not exclusively, corporations) to bring their own claim against governments. ${ }^{54-56}$ Capital exporting states' continuing preference for ISDS provisions in international agreements is attributed to the belief that overseas corporations are more likely to prevail before an investment tribunal than in domestic courts ${ }^{57}$ and their increasing significance is underlined by a fivefold increase in cases under the World Bank's international arbitration body, the International Centre for the Settlement of Investment Disputes (ICSID), between 1999 and 2012. ${ }^{25}$ In practice, ISDS is either overseen by a supervising institution, such as the ICSID $^{54} 58$ or simply follows established rules, such as those of the United Nations Commission on International Trade Law. ${ }^{58}$ A leaked draft of the TPP's investment chapter suggests that claimants will be free to submit claims under the TPP to either the ICSID or under UNICTRAL Arbitration Rules or, where claimant and respondent agree, to any other arbitration institution or under any other arbitration rules. ${ }^{34}$

One reason PMI is likely to favour ISDS stems from its capacity to discourage parties from introducing plain packaging and produce what is commonly described as 'regulatory chill'. 59 Although this phenomenon is characteristic of WTO rules and dispute settlement, ISDS is likely to produce a greater chilling effect for several reasons. The first concerns the existence of a pro-business decision-making culture cultivated by arbitral rules and working practices. Arbitral adjudicators are typically international investment lawyers drawn from commercial practice with no expertise in public health which raises questions about their competence to judge the efficacy of public health regulation and take account of the public policy consequences of their decisions. ${ }^{54}$ 60-63 Arbitral rules also allow lawyers to rotate between roles as arbitrators and advocates for investors in a way that provides limited protection for conflicts of interest. ${ }^{25} 5464$ Estimates suggest over $50 \%$ of arbitrators act as counsel for investors in other cases while just $10 \%$ act for states. ${ }^{54}$ Conflicts can arise when arbitrators have ongoing interests in other cases. ${ }^{54}$ Moreover, arbitrators are typically appointed and compensated by the parties to the dispute, ${ }^{54}$ which may bias decisions in favour of corporate actors who frequently use arbitration. ${ }^{54}$ Although repeated appointments of an arbitrator by the same company or law firm are commonly addressed in arbitral rules, repeated appointments by the same side of the investor-state divide are not. ${ }^{65}$ These concerns are consistent with the criticism that arbitrators broadly interpret the language contained in investment treaties in a way that prioritises transnational corporations' economic interests over governments' right to regulate. ${ }^{6366} 67$

Another reason ISDS is likely to produce a more powerful chilling effect than the WTO's dispute settlement process concerns the fact that companies can initiate complaints directly, rather than having to lobby a state to act on their behalf. One consequence of this is that the remedies arbitral tribunals can impose on legislating states (compensation or injunctive relief) are linked to the losses incurred by companies from breaches of agreements. In the case of compensation the sums claimed can be vast. Under the Australia-Hong Kong Bilateral Investment Treaty (BIT) (see box 1), Philip Morris Asia (PM Asia) is using ISDS to seek 'billions of (Australian) dollars' for potential losses arising from the 2011 Plain Packaging Act and new graphic health warning regulation. ${ }^{68-70}$ The chilling effect is likely to be greater still for low and middle income countries as the calculation of compensation is not tied to their ability to pay. ${ }^{54} \mathrm{By}$ contrast, under the WTO's dispute settlement process (box 3), complainant states are effectively limited to imposing retaliatory sanctions commensurate with the value of trade lost resulting from the legislating state's non-compliance with General Agreement on Tariffs and Trade (GATT)/WTO rules. ${ }^{71-74}$ In pure economic terms, this makes WTO dispute settlement a weaker deterrent to governments considering plain packaging legislation, particularly where the trade in tobacco between legislating and complainant states is not significant, the volume of trade lost to a complainant state is small, ${ }^{75} 76$ or where complainant states' economies are relatively undeveloped, as this limits their capacity to retaliate in kind. ${ }^{77} 78$

Tobacco companies' problems in working through member states under the WTO's system of dispute settlement is compounded by the fact that many governments may be averse to acting on behalf of tobacco companies. Similarly, low and middle income countries may have concerns about disrupting relations with a more powerful trading partner or a geostrategic ally. ${ }^{77}$ 79-82 By reducing the pool of states that tobacco companies can rely on to initiate a complaint these factors can limit the potential size of the sanctions on legislating states. These limitations of WTO dispute settlement for the tobacco industry are illustrated by the current complaint against Australia in the WTO. Although Ukraine, the lead complainant in this case, is the site of a PMI subsidiary that employs 1400 workers, it has not traded any tobacco with Australia since at least $2005 .^{83-85}$

ISDS is also likely to create a larger deterrent effect because of the greater uncertainty inherent in ISDS decisions. ${ }^{86}$ In principle, neither adopted WTO panel and Appellate Body reports, nor decisions of ISDS investment tribunals are formally binding on third parties not involved in the adjudicated dispute. ${ }^{60}$ However, in contrast to ISDS tribunals, the WTO operates a de 
facto system of precedent. ${ }^{87} 88$ While ISDS tribunals cite previous cases in support of decisions, they do not have to base their decisions on those of previous cases. This produces competing lines of case law which provide a jurisprudential basis for tribunals to arrive at different conclusions in effectively identical cases. ${ }^{11} 588990$ The absence of an appellate body in investment arbitration and the limited scope to have decisions reviewed is likely to compound this effect. ${ }^{58} 8082$

The lack of transparency in investor-state disputes presents an additional source of uncertainty. Proceedings are held in-camera and once a ruling is made by a tribunal there is no general requirement to publish the award or the basis upon which it is made $^{5891}$ The World Bank's ICSID is now required to make public information on the registration of all requests for conciliation or arbitration, the date and method of termination of proceedings, and, with the consent of the parties, reports of conciliation commissions and awards (where consent is not forthcoming excerpts of the legal reasoning behind tribunal decisions are still published). ${ }^{92}$ By contrast, no organisation keeps track of United Nations Commission on International Trade Law disputes. ${ }^{93}$ This lack of transparency creates an information imbalance, which puts low income and middle income countries at a disadvantage as investors with the financial resources to hire major international law firms specialising in this area enjoy greater access to this disparate body of arbitral decisions through professional networks. ${ }^{58} 94$

These above issues increase the litigation risks for states, which is likely to have a bearing on the decision of low income and middle income countries to withdraw innovative tobacco control measures, or not to innovate at all. The problem is compounded by the high administrative costs involved, which, according to a recent survey by the Organisation of Economic Co-Operation and Development, average over US $\$ 8$ million per case. $^{3} 54589596$ Moreover, rules for allocating costs among parties are flexible and considered to be an additional source of uncertainty. ${ }^{54}$

\section{'A HIGH STANDARD OF PROTECTION FOR TRADEMARKS': EXTENDED PROTECTION FOR IP TRIPS and 'TRIPS-plus'}

Shortly after TRIPS came into effect, the USA and other developed nations began negotiating for broader and more extensive coverage, increased harmonisation and stronger enforcement mechanisms. ${ }^{559798}$ Efforts were also made to weaken 'flexibilities' and 'special and differential treatment' granted to developing countries in a process commonly referred to as 'TRIPS-Plus'. ${ }^{16}{ }^{55}{ }^{97-100}$ In the present case, PMI's reply to the US Federal Register indicates that it specifically called for a 'TRIPS-plus' chapter to allow it to challenge the introduction of plain packaging. ${ }^{33}$

The reason behind the request may stem from concerns within PMI that the protection TRIPS gives tobacco companies over pack design is weak or equivocal. ${ }^{101} 102$ Tobacco companies have consistently argued that plain packaging contravenes several TRIPS provisions; including Articles 15.4 and 20 and Paris Convention Article 6 quinquies (B). ${ }^{103-108}$ However, there is a measure of consensus among academic lawyers that the rights granted under TRIPS Article 15.4 and Article 6 quinquies of the Paris Convention are confined to the registration of trademarks, rather than their use and are, therefore, unaffected by plain packaging. ${ }^{102}{ }^{109-113}$ There is also a measure of consensus that the strongest argument raised by tobacco companies is that plain packaging violates TRIPS Article 20. Article 20 provides that the use of a trademark in the course of trade should not be unjustifiably encumbered by special requirements. ${ }^{114}$ Plain packaging is clearly a 'special requirement' which is detrimental to the capability of a trademark to distinguish between tobacco products from different companies. ${ }^{102}$ However, it may be justifiable by virtue of being necessary for public health. ${ }^{11}$ This interpretation of justifiable is reinforced by Article 8(1), which permits WTO members to adopt measures necessary to protect public health provided they are broadly consistent with other provisions within TRIPS. ${ }^{102} 106$ Tobacco companies have argued that the proviso merely affirms the right of WTO members to make public policy and does not empower them to breach the provisions of TRIPS. ${ }^{11} 103104$ The provision has not yet been the focus of a WTO ruling. ${ }^{115}$ However, the industry's interpretation contradicts Paragraph 4 of the Doha Declaration on TRIPS and Public Health (see box 2) and is inconsistent with the WTO Appellate Body's (see box 3) interpretation of necessary in the context of Article XX(b) of GATT 1994 (see box 4). ${ }^{116} 117$

\section{Expropriation and minimum standard of treatment}

Although a leaked draft chapter on IP proposed by the USA suggests that it is proposing language which might create an affirmative right to use trademarks under certain conditions, in practice this might not prove as important to the prevention of plain packaging than the protections provided to IP in the TPP's chapter on investment. ${ }^{11} 3436118$ A leaked draft of that chapter defines investment broadly as applying to any assets whose characteristics include 'a commitment of capital or other resources, expectation of gain or profit, or assumption of risk, ${ }^{34}$ which potentially extends the expropriation and minimum standards of treatment provisions in the chapter to the use of trademarks and, therefore, pack design.

Draft Article 12.12 within this chapter requires compensation for 'indirect expropriation' of 'covered investments' where the effect is to reduce the value of a company's investments and its future profits. ${ }^{34}$ Some tribunals have set the threshold at which compensation is payable at a significant and substantial loss, while others have required the near destruction of the value of the investment. ${ }^{11} 119$ PM Asia's complaint under the Hong Kong-Australia BIT (box 1) seems to have been drafted with this latter line of cases in mind, arguing that the 2011 Act 'virtually eliminates PM's branded business by expropriating its valuable intellectual property', transforming the company to a 'manufacturer of commoditized products with the consequential effect of substantially diminishing the value of PM Asia's investments in Australia'. ${ }^{69} 70$ Two (presumably alternative) draft annexes to the chapter aim to limit the use of indirect expropriation. Annex $12-C$ proposes a 'case-by-case' inquiry that considers the economic impact of public policy, the extent to which it interferes with 'reasonable investment-backed expectations', and the

\section{Box 2 Paragraph 4 of the Doha Declaration}

Paragraph 4 of the Declaration states that TRIPS 'does not and should not prevent Members from taking measures to protect public health' and 'should be interpreted in a manner supportive of World Trade Organisation members' right to protect public health'. Although the Declaration has been argued to have the same effects as an authoritative interpretation, ${ }^{144}$ its substantive scope is restricted to access to medicines for pandemics. ${ }^{11}$ 
Box 3 World Trade Organisation (WTO) dispute settlement process ${ }^{145}$

The Dispute Settlement Body (DSB) consists of all WTO members and has the responsibility for settling disputes under General Agreement on Tariffs and Trade (GATT)/WTO rules. It establishes panels of experts to consider cases in response to requests from complainant states. The panel produces a report which, in practice, becomes the DSB's ruling at which point it can be appealed by either side. Appeals are adjudicated by three members of a rotating seven-member Appellate Body broadly representative of the WTO's membership. The appeal can uphold, modify or reverse the panel's legal findings and conclusions. Rejection of an appeal report by the DSB is only possible by consensus.

If the respondent state fails to comply with a ruling within a reasonable period, it is required to enter into negotiations with the complainant state to determine mutually acceptable compensation. In the absence of an agreement the complainant can apply to the DSB for permission to impose trade sanctions against the respondent. In principle, the sanctions should be imposed in the same sector as the dispute. If this is not practical or effective, the sanctions can be imposed in a different sector under the same agreement or, in exceptional cases, under another WTO agreement.

'character of government action'. Annex 12-D, by contrast, refers to interference with intangible property rights or interests in an investment that are either 'severe' or 'for an indefinite period' and 'disproportionate to the public purpose. ${ }^{34}$ These terms are untested and subject to exceptions ('except in rare circumstances') which provide arbitrators with some discretion to rule against policies made in good faith to protect public health, and, therefore, create uncertainty in how the protection will be interpreted. ${ }^{34}$

The broad definition of investment also potentially extends the 'minimum standard of treatment' protection under draft Article 12.6.1 to trademarks use. ${ }^{34}$ The minimum standard includes 'fair and equitable treatment' ${ }^{\text {' }}$ which has been interpreted by tribunals under existing agreements to include a right to a 'stable and predictable business environment' that does not stymie investors' expectations concerning the profitability or value of their investments. ${ }^{119}$ Factors considered relevant to the measure include the contribution of the investment to the country, whether the policy is considered arbitrary or unreasonable, and the status of government policy at the time the investment is made. ${ }^{11} 119$ Tribunal decisions on the scope of the protection are divergent and, as such, the standard creates a further source of uncertainty. ${ }^{119}$

\section{THE TOBACCO-SPECIFIC EXCEPTION}

Despite the risks these provisions pose in extending tobacco companies' IP rights, the USTR has announced that the authority of countries to enact measures aimed at reducing tobacco use will be protected under the TPP. ${ }^{120-124}$ US government agencies are formally prohibited from seeking to reduce or remove other nations' non-discriminatory restrictions on tobacco marketing. ${ }^{125-128}$ Consequently, the USTR has produced a draft proposal which would include language in the 'general exceptions' chapter partially carving out tobacco in the TPP. ${ }^{129}$ Although
Box 4 Appellate body's report into Brazil's measures affecting imports of retreaded tyres ${ }^{102} 116117$

General Agreement on Tariffs and Trade (GATT) Article XX(b) exempts a Member's measure from compliance with the provisions of GATT where that measure is 'necessary to protect human, animal or plant life or health. ${ }^{117}$ In 2007 the World Trade Organisation (WTO)'s Appellate Body outlined the following principles which, if subsequently applied to Article 8 , are unlikely to favour Ukraine's current complaint in the WTO:102 116117

- Certain complex public health or environmental problems may be tackled only with a comprehensive policy comprising a multiplicity of interacting measures;

- In the short term it may prove difficult to isolate the contribution to public health of one specific measure from those attributable to the other measures that are part of the same comprehensive policy;

- Results obtained from certain preventive actions to reduce the incidence of diseases may manifest themselves only after a certain period of time and may only be capable of evaluation after a period of time;

- An import ban under Article XX(b) can only be justified where it brings about a material contribution to the achievement of its objective;

- A material contribution can be established with reference to evidence or data but also on the basis of quantitative projections in the future, or qualitative reasoning based on a set of hypotheses that are tested and supported by sufficient evidence;

- The selection of a methodology to assess a measure's contribution is a function of the nature of the risk, the objective pursued, and the level of protection sought, and depends on the nature, quantity and quality of evidence existing at the time the analysis is made. ${ }^{117}$

not formally proposed in negotiation at the time of writing, a recently published (May 2012) USTR factsheet on the proposal states it would allow health authorities to adopt regulations that impose 'science-based restrictions on specific tobacco products/ classes in order to safeguard public health'. ${ }^{129} 130$ The USTR claims that this language will create a 'safe harbour' for tobacco regulation, providing 'greater certainty' that the provisions in the TPP will not be used to prevent regulation aimed at promoting public health, 'while retaining important trade disciplines (national treatment, compensation for expropriations and transparency) on tobacco measures.'129

In its present form the degree of protection this proposal would give to public health policy is unclear. The proposal covers regulations adopted by a health authority and, therefore, potentially does not extend to legislation or regulations by nonhealth authorities on matters relating, for example, to tax and IP. ${ }^{131}$ In addition to this, the proposal does not seem to extend to claims alleging that regulation has had the effect of expropriating a company's assets without providing compensation. ${ }^{131}$ The 'science-based' test also creates uncertainty. It represents a qualitatively different test to Article 8(1) of TRIPS and may impose a more rigid process of evaluation than that outlined by the Appellate Body in relation to Article XX(b) of GATT 1994 (box 4). The health exception in GATT applies to measures that 
are 'necessary.' The WTO's Appellate Body has ruled that a necessary measure must contribute to the health objective, but the contribution need not be proven with 'science-based' evidence (see box 4). In this regard, the proposed exception may be narrower than the existing health exception. Moreover, by creating uncertainty and providing another avenue for tobacco companies to litigate it is likely to discourage parties from introducing plain packaging. ${ }^{131}$

\section{CONCLUSION}

Trade and investment agreements have been criticised for transferring state decision-making from the national to the international level and providing transnational corporations with a supranational court of appeal with which to challenge the capacity of governments to introduce new public health legislation. ${ }^{27} \mathrm{PM}$ Asia's continuing action against the Australian government under the Hong Kong-Australia BIT given its defeat in the Australian High Court over the 2011 Act illustrates this point well. ${ }^{70} 132$ PMI's formal request to the USTR that the TPP be used to extend IP rights, harmonise the process of regulatory formation, and provide a comprehensive system of ISDS reflect the contents of leaked drafts of the TPP agreement. These suggest the TPP will extend IP protection to trademark use, strengthen corporate influence in regulatory formation, and provide tobacco companies with extensive powers to litigate against governments directly. Although the extension of IP protection is subject to exceptions for measures aimed at promoting public health, the precise scope of these exceptions is unclear. Consequently, all three measures are likely to increase the tobacco industry's policy influence and to deter governments from introducing plain packaging, albeit in different ways. First, by increasing litigation risk for legislating states, the extension of IP protection to trademark use will increase tobacco companies' power to present the costs associated with plain packaging and other policies affecting pack design as prohibitively expensive. Likewise, proposals such as regulatory review, stakeholder consultation and the use of impact assessments provide the industry with a range of tools to access and feed information into health policymaking. Combined with the TPP's proposal for states to provide access to 'supporting documentation' relating to regulatory measures, analyses and data, which may exacerbate existing information asymmetries between states and multinational corporations, these reforms are likely to facilitate challenges to regulatory innovation under international law. ${ }^{23}$ By underpinning these measures with ISDS, which increases the economic costs associated with litigation and institutionally embeds uncertainty in treaty interpretation, the TPP provides a powerful new toolbox for the industry in preventing the introduction of plain packaging and other innovative health measures.

Finally, the lack of transparency in the TPP negotiations illustrates the limitations inherent in the state-centric nature of Article 5.3 of the WHO Framework Convention on Tobacco Control. Article 5.3 aims to limit tobacco industry involvement in health policy by, among other things, requiring parties to the Convention to make interactions between the tobacco industry and public officials as transparent as possible. The USA is a nonparty to the Convention and is, therefore, under no obligation to make public any involvement of tobacco companies, either directly or through third parties, in TPP policymaking. This enables the tobacco industry to undermine APEC states' efforts to implement Article 5.3 and influence health policy remotely through TPP negotiations.
Key messages

- The TPP threatens to increase the tobacco industry's policy influence and increase the litigation risks of plain packaging legislation and other innovative tobacco control measures.

- Parties to the Framework Convention on Tobacco Control should consider how Article 5.3 can be implemented to prevent tobacco companies from influencing public health policy remotely through trade and investment agreements.

- Agreements involving non-party states raise additional complications which need to be raised during treaty negotiations.

Acknowledgements We thank Cathy Flower for providing administrative support for the project and Jeff Collin for advice on relevant sources. The study was supported by Grant Number R01CA160695 from the National Cancer Institute at the US National Institutes of Health. The content is solely the responsibility of the authors and does not necessarily represent the official views of the National Cancer Institute or the National Institutes of Health. Gary Fooks and Anna Gilmore are members of the UK Centre for Tobacco Control Studies (UKCTCS), a UK Centre for Public Health Excellence. Funding to UKCTCS from the British Heart Foundation, Cancer Research UK, the Economic and Social Research Council, the Medical Research Council and the National Institute of Health Research, under the auspices of the UK Clinical Research Collaboration, is gratefully acknowledged.

Contributors The study was conceived and designed by GF. GF analysed the data and wrote the first draft of the manuscript. $A B G$ contributed to the writing of the manuscript. ICMJE criteria for authorship are met. GF and ABG agree with manuscript results and conclusions.

\section{Competing interests None.}

Provenance and peer review Not commissioned; externally peer reviewed.

Open Access This is an Open Access article distributed in accordance with the Creative Commons Attribution Non Commercial (CC BY-NC 3.0) license, which permits others to distribute, remix, adapt, build upon this work non-commercially, and license their derivative works on different terms, provided the original work is properly cited and the use is non-commercial. See: http://creativecommons.org/ licenses/by-nc/3.0/

\section{REFERENCES}

1 Shaffer ER, Brenner JE, Houston TP. International trade agreements: a threat to tobacco control policy. Tob Control 2005; 14:ii19-25.

2 MacKenzie R, Collin J. 'Trade policy, not morals or health policy': the US Trade Representative, tobacco companies and market liberalization in Thailand. Global Soc Policy 2012;12:149-72.

3 Callard C, Chitanondh H, Weisman R. Why trade and investment liberalisation may threaten effective tobacco control efforts. Tob Control 2001;10:68-70.

4 McGrady B. Trade liberalisation and tobacco control: moving from a policy of exclusion towards a more comprehensive policy. Tob Control 2007;16:280-3.

5 Zhong F, Yano E. British American Tobacco's tactics during China's accession to the World Trade Organization. Tob Control 2007;16:133-7.

6 Lee S, Holden C, Lee K. Are transnational tobacco companies' market access strategies linked to economic development models? A case study of South Korea. Global Public Health 2013:8:1-14.

7 Holden C, Lee K, Gilmore A, et al. Trade policy, health and corporate influence: British American Tobacco and China's accession to the World Trade Organization. Int J Health Serv 2010;40:421-41.

8 Collin J. Tobacco control, global health policy and development: towards policy coherence in global governance. Tob Control 2012;21:274-80.

9 Campaign for Tobacco-Free Kids. Tobacco and trade. http://www.tobaccofreekids. org/what_we_do/federal issues/trade/ (accessed 14 Sep 2012).

10 Action on smoking and health. Hidden hand of big tobacco leads to WTO challenge. 20 August 2012. http://ash.org/hidden-hand-of-big-tobacco-leadsto-wto-challenge/ (accessed 15 Sep 2012).

11 Kelsey J. International trade law and tobacco control. 2012. http://www.turanga. org.nz/sites/turanga.org.nz/files/Kelsey\%20Trade\%20Law\%20Tobacco\%20Control \%20Report.pdf (accessed 3 Jan 2013).

12 Nebehay S. Australia says big tobacco aiding WTO challengers. 23 May 2012. http://www.reuters.com/article/2012/05/23/us-trade-tobaccoidUSBRE84M0I020120523 (accessed 10 Mar 2013). 
13 Tienhaara K, Faunce T. Gillard must repel big tobacco's latest attack. Canberra Times 28 June 2011. http://www.canberratimes.com.au/news/opinion/editorial/ general/gillard-must-repel-big-tobaccos-latest-attack/2209168.aspx (accessed 15 Sep 2012)

14 McGrady B. Implications of ongoing trade and investment disputes concerning tobacco: Philip Morris v. Uruguay. In: Tania Voon AM, Liberman J, Ayres G, eds. Public health and plain packaging: legal issues. Edward Elgar, 2012:173-99.

15 Voon T, Mitchell A. Time to quit? Assessing international investment claims against plain tobacco packaging in Australia. J Int Econo Law 2011;14:1-35.

16 McGrady B. Confronting the tobacco epidemic in a new era of trade and investment liberalization. 2012. http://whqlibdoc.who.int/publications/2012/ 9789241503723_eng.pdf (accessed 14 Jan 2013).

17 Bozick T. Companies push to keep tobacco in trade agreement. 23 March 2012. http://www2.wsls.com/news/2012/mar/23/companies-push-keep-tobacco-tradeagreement-ar-1789898/ (accessed 14 Sep 2012).

18 Capling A. Multilateralising PTAs in the Asia-Pacific Region: a comparison of the ASEAN-Australia-NZ FTA and the P4 agreement. Asia Pacific Trade Economists' Conference ARTNeT, 2-3 November 2009, Decided. http://www.unescap.org/tid/ artnet/mtg/2-2Ann\%20Capling.pdf (accessed 15 Oct 2012).

19 Herreros S. The Trans-Pacific Strategic Economic Partnership Agreement: a Latin American perspective. 2011, Serie Comercio internacional No. 106. http://www. eclac.org/comercio/publicaciones/xml/6/42966/Transpacific_strategic_economic_ partnership_Latin_American_serie_106.pdf (accessed 15 Oct 2012).

20 Government of Brunei Darussalam, Government of the Republic of Chile, Government of New Zealand, et al. Trans-Pacific Strategic Economic Partnerships Agreement. 2005. http://www.mfat.govt.nz/downloads/trade-agreement/ transpacific/main-agreement.pdf (accessed 15 Oct 2012).

21 Reuters. Asia-Pacific trade talks entering delicate phase: U.S. 12 September 2012 http://www.reuters.com/article/2012/09/12/us-usa-asia-tradeidUSBRE88B1G320120912 (accessed 14 Sep 2012).

22 Department of Foreign Affairs. Trans-Pacific partnership agreement negotiations. http://www.dfat.gov.au/fta/tpp/index.html (accessed 9 Oct 2012).

23 Kelsey J. The implications of new generation free trade agreements for alcohol policies. 30 September. http://www.converge.org.nz/watchdog/29/08.htm (accessed 9 Oct 2012).

24 Fergusson IF, Cooper WH, Jurenas $\mathrm{R}$, et al. The Trans-Pacific partnership negotiations and issues for Congress. CSR Report for Congress 2012 November 21; 7-5700 (R42694). http://www.fas.org/sgp/crs/row/R42694.pdf (accessed 5 Jan 2013).

25 Evatt EA, Thomas E, Woodhouse 0 , et al. An open letter from lawyers to the negotiators of the Trans-Pacific partnership urging the rejection of Investor-State Dispute Settlement. 8 May 2012 http://tpplegal.wordpress.com/open-letter/ (accessed 9 Oct 2012)

26 Tienhaara K. Investor-State Dispute Settlement in the Trans-Pacific Partnership Agreement. Submission to the Department of Foreign Affairs and Trade 2010. http://www.dfat.gov.au/fta/tpp/subs/tpp_sub_tienhaara_100519.pdf (accessed 11 Oct 2012)

27 Baker D. The Pacific free trade deal that's anything but free. The Guardian. 27 August 2012. http://www.guardian.co.uk/commentisfree/2012/aug/27/ pacific-free-trade-deal\#start-of-comments (accessed 15 Sep 2012).

28 Martin P. Big Tobacco warning at free-trade talks. Sydney Morning Herald. 11 September 2012. http://www.smh.com.au/business/world-business/big-tobaccowarning-at-freetrade-talks-20120911-25qam.html (accessed 15 Sep 2012).

29 Martin P. Hidden hand of big tobacco leads to WTO challenge. Sydney Morning Herald. 20 August 2012. http://www.smh.com.au/opinion/political-news/ hidden-hand-of-big-tobacco-leads-to-wto-challenge-20120819-24gjo.html (accessed 10 Oct 2012).

30 Choudhury B. Recapturing public power: is investment arbitration's engagement of the public interest contributing to the democratic deficit. Vanderbilt J Transnational Law 2008:41:775-832.

31 Wallach L. NAFTA on Steroids. The Nation 2012. http://www.thenation.com/article/ 168627/nafta-steroids\# (accessed 15 Sep 2012).

32 Asia Pacific Camara de Comercio, Australian Chamber of Commerce and Industry, Canadian Manufacturers and Exporters, et al,. Finish an Ambitious TPP in 2013, say Asia Pacific Business Leaders. 2012. http://www.nftc.org/default/Press\% 20Release/2012/090412\%20Statement\%20of\%20Asia-Pacific\%20Business\% 20Leaders.pdf(accessed 27 Feb 2013).

33 Philip Morris International. Submission of Philip Morris International in Response to the Request for Comments Concerning the Proposed Trans-Pacific Partnership Trade Agreement. 2010. http://www.regulations.gov/search/Regs/home. html\#documentDetail?R=0900006480a81299 (accessed 17 Sep 2012).

34 Trans-Pacific Partnership. Investment (draft text). 2012. http://www.citizenstrade.org/ ctc/wp-content/uploads/2012/06/tppinvestment.pdf (accessed 27 February 2013).

35 Trans-Pacific Partnership. Regulatory coherence (draft text). 2010. http://www citizenstrade.org/ctc/wp-content/uploads/2011/10/TransPacificRegulatoryCoherence. pdf (accessed 11 October 2012).

36 Trans-Pacific Partnership. Intellectual property rights chapter february draft-10 February 2011. 2011. http://keionline.org/sites/default/files/tpp-10feb2011us-text-ipr-chapter.pdf (accessed 26 Oct 2012).
37 Smith KE, Fooks G, Collin J, et al. "Working the system"—British American tobacco's influence on the European Union Treaty and its implications for policy: an analysis of internal tobacco industry documents. PLoS Med 2010;7:e1000202.

38 Smith KE, Fooks G, Collin J, et al. Is the increasing policy use of impact assessment in Europe likely to undermine efforts to achieve healthy public policy? J Epidemiol Community Health 2010;64:478-87.

39 Kingsbury B, Krisch N, Stewart RB. The emergence of global administrative law. Law Comtemporary Probl 2005;68:15-62.

40 Wiener JB. Better regulation in Europe. Curr Legal Prob/ 2006;59:447-518.

41 Kelsey J. Preliminary analysis of the draft TPP chapter on domestic coherence. http://www.citizenstrade.org/ctc/wp-content/uploads/2011/10/ TransPacific RegCoherenceMemo.pdf (accessed 22 Sep 2012).

42 Office of the United States Trade Representative. Technical barriers to trade report 2012. http://www.ustr.gov/webfm send/3323 (accessed 27 Feb 2013).

43 Bouwen P. Corporate lobbying in the European Union: the logic of access. J Eur Public Policy 2002;9:365-90.

44 Hansen JM. Gaining access. Chicago: University of Chicago Press, 1991.

45 Eising R. The access of business interests to EU institutions: towards Elite pluralism? J Eur Public Policy 2007;14:384-403.

46 Bouwen P, McCown M. Lobbying versus litigation: political and legal strategies of interest representation in the European Union. J Eur Public Policy 2007;14:422-43.

47 Woll C. Leading the dance? Power and political resources of business lobbyists. J Public Policy 2007;27:57-78.

48 Beyers J. Voice and access: political practices of European interest associations. Eur Union Polit 2004;5:211-40.

49 APEC. Information notes on good practice for technical regulation. 2000. http://www.jisc.go.jp/eng/apec-asem/pdf/grp_info.pdf (accessed 10 Oct 2012.

50 Australian Government Department of Finance and Deregulation. Office of best practice regulation. http://www.finance.gov.au/obpr/about/ (accessed 22 Oct 2012).

51 British American Tobacco Australia. Submission on the Tobacco Plain Packaging Bill 2011. In: Australian Government Department of Health and Aging, ed. National health reform. 2011. http://www.health.gov.au/internet/yourhealth/ publishing.nsf/Content/british-american-tobacco-australia\#.UIBe2vUlqSo (accessed 18 Oct 2012).

52 Fooks GJ, Gilmore AB, Smith KE, et al. Corporate social responsibility and access to policy elites: an analysis of tobacco industry documents. PLoS Med 2011;8:e1001076.

53 Smith KE, Gilmore AB, Fooks $G$, et al. Tobacco industry attempts to undermine Article 5.3 and the "good governance" trap. Tob Control 2009;18:509-11.

54 Organisation of Economic Co-Operation and Development. Investor-State Dispute Settlement. Public Consultation: 16 May-9 July 2012. 2012. http://www.oecd.org/ daf/inv/internationalinvestmentagreements/50291642.pdf (accessed 12 Jan 2013).

55 Yu PK. TRIPS and its Achilles' heel. J Intellect Property Law 2011;18:479-531.

56 United Nations Conference on Trade and Development. Dispute settlement: investor-state UNCTAD issues in international investment agreements 2003. http://unctad.org/en/docs/iteiit30_en.pdf (accessed 27 Feb 2013).

57 Trakman L. Resolving investor-state disputes under a Transpacific Partnership Agreement. University of New South Wales Faculty of Law Research Series 2012 http://law.bepress.com/cgi/viewcontent.cgi?article=1378\&context=unswwps-flrps 12 (accessed 8 Oct 2012).

58 Tienhaara K. What you don't know can hurt you: investor-state disputes and the protection of the environment in developing countries. Global Environ Polit 2006:6:73-100.

59 Tienhaara K. Regulatory chill and the threat of arbitration: a view from political science. In: Brown C, Miles K, eds. Evolution in investment treaty law and arbitration. Cambridge: Cambridge University Press, 2011:606-28.

60 Trackman L. The ICSID under siege. Faculty of Law Research Series 2012; Working Paper 6. http://law.bepress.com/cgi/viewcontent.cgi?article=1338\&context= unswwps-flrps12 (accessed 10 Oct 2012).

61 Salacuse JW. The law of investment treaties 1. Oxford: Oxford University Press, 2010.

62 Malintoppi L. Independence, impartiality, and duty of disclosure of arbitrators. In: Muchlinski P, Ortino F, Schreuer C, eds. Oxford handbook of international investment law. Oxford, Oxford University Press: 2008:153-80.

63 Ganguly S. The investor-state dispute mechanism (ISDM) and a sovereign's power to protect public health. Columbia J Transnational Law 1999;38:113-68.

64 Coe J. Transparency in the resolution of investor-state disputes: adoption, adaption, and NAFTA leadership. Uni Kansas Law Rev 2006;54:1351-2.

65 Buergenthal T. The proliferation of disputes, dispute settlement procedures and respect for the rule of law. Arbitration Int 2006;22:495-9.

66 van Harten G. Public statement on the international investment regime. 2010. http://www.pc.gov.au/_data/assets/pdf_file/0005/102488/subdr067-attachment2. pdf (accessed 11 Oct 2012)

67 Faunce TA, Townsend R. The Trans-Pacific Partnership Agreement: challenges for Australian health and medicine policies. Med J Aust 2011;194:83-6.

68 Magnus J. Compliance with WTO dispute settlement decisions: is there a crisis? In: Yerxa R, Wilson B, eds. Key issues in WTO dispute settlement: the first ten years. Cambridge: Cambridge University Press 2005:242-50. 
69 Agreement between the Government of Australia and the Government of Hong Kong for the Promotion and Protection of Investments. 1993 Date. http://www. austlii.edu.au/au/other/dfat/treaties/1993/30.html (accessed 6 Jan 2012).

70 Allens Arthur Robinson. Notice of claim under the Australia/Hong Kong agreement for the promotion and protection of investments. 15 July 2011). http://www.ag. gov.au/Internationalrelations/InternationalLaw/Documents/Philip\%20Morris\% 20Asia\%20Limited\%20Notice\%20of\%20Claim\%2027\%20June\%202011.pdf (accessed 6 Jan 2013).

71 European Communities-Measures Concerning Meat and Meat Products (Hormones) - Recourse to arbitration by the European Communities under Article 22.6 of the DSU. World Trade Organization 1999, July 12; WT/DS26/ARB. http:// docsonline.wto.org/imrd/directdoc.asp?DDFDocuments/t/WT/DS/26ARB.DOC (accessed 19 Oct 2012).

72 WTO Analytical Index: dispute settlement understanding: understanding on rules and procedures governing the settlement of disputes. Article 22.4. http://www. wto.org/english/res_e/booksp_e/analytic_index_e/dsu_08_e.htm\#article22 (accessed 13 Oct 2012).

73 European Communities-Regime for the importation, sale and distribution of bananas-recourse to arbitration by the European Communities under Article 22.6 of the DSU. World Trade Organization 9 April 1999; WT/DS27/ARB. http:// docsonline.wto.org/imrd/directdoc.asp?DDFDocuments/t/WT/DS/27ARB.DOC

74 United States-Continued Dumping and Subsidy Offset Act of 2000 (Original Complaint by Brazil) — recourse to arbitration by the United States under Article 22.6 of the DSU. World Trade Organization 31 August 2004; WT/DS217/ARB/ BRA. http://docsonline.wto.org/imrd/directdoc.asp?DDFDocuments/t/WT/DS/ 217ARBBRA.doc

75 World Health Organization. Background paper. Workshop on trade-related issues relevant to implementation of the WHO FCTC. http://www.who.int/fctc/ 1-1-1-Summary Workshop Content EN.pdf accessed 19 Oct 2012).

76 Voon T, Mitchell A. Face off: assessing WTO challenges to Australia's scheme for plain tobacco packing. Public Law Rev 2011;22:218-40.

77 Bown CP. Participation in WTO dispute settlement: complainants, interested parties, and free riders. World Bank Econ Rev 2005;19:287-310.

78 Bagwell K, Mavroidis PC, Staiger RW. The case for tradable remedies in WTO dispute settlement. In: Evenett SJ, Hoekman BM, eds. Economic development and multilateral trade cooperation. Basingstoke: Palgrave Macmillan/World Bank, 2006:395-413.

79 Chang P-L. The evolution and utilization of the GATT/WTO dispute settlement mechanism. Research Seminar Series in International Economics 19 April 2002, Discussion Paper No. 475. http://www.fordschool.umich.edu/rsie/workingpapers/ Papers451-475/r475.pdf (accessed 16 Oct 2012).

80 Chang P-L, Hartigan JC. The Evolution and utilization of the Gatt/WTO dispute settlement mechanism. Research Collection School of Economics 2007; Working Paper 1036. http://ink.library.smu.edu.sg/cgi/viewcontent.cgi? article $=2035 \&$ context $=$ soe research (accessed 10 Oct 2012)

81 Wilckens S. The usage of the WTO dispute settlement system: do power considerations Matter? In: Hartigan JC, ed. Trade disputes and the dispute settlement understanding of the WTO: an interdisciplinary assessment. Bingley: Emerald Group Publishing, 2009:213-41.

82 Garrett G, Smith JM. The politics of WTO dispute settlement. Occasional Paper Series, UCLA International Institute, UC Los Angeles 31 July 2002. http://www. international.ucla.edu/cms/files/july02io.pdf (accessed 15 Oct 2012).

83 Martin P. Australia challenges Ukraine on tobacco. The Sydney Morning Herald. 3 September 2012. http://www.smh.com.au/national/health/australia-challengesukraine-on-tobacco-20120902-258hv.html (accessed 10 Oct 2012).

84 Winstanley M. The tobacco industry in Australian society. In: Scollo M, Winstanley M, eds. Tobacco in Australia: facts and issues. Victoria: Cancer Counci Victoria, 2008:11-5.

85 Ukraine Files WTO Complaint over Australian Tobacco Law. RIA Novosti. 15 March 2012. http://en.rian.ru/business/20120315/172180945.html (accessed 22 Oct 2012).

86 Douglas Z. The international law of investment claims. Cambridge: Cambridge University Press, 2009.

87 International trade law-role of dispute settlement decisions in WTO law-WTO appellate body reaffirms WTO-inconsistency of "zeroing." - appellate body report, "United States - final anti-dumping measures on stainless steel from Mexico", WT/DS344/AB/R (30 April 2008). Harv Law Rev 2009;122:1993-2000.

88 Bhala R. The myth about Stare decisions and international trade law (part one of a trilogy). Am Univ Int Law Rev 1999;14:845-956.

89 Franck SD. The legitimacy crisis in investment treaty arbitration: privatizing public international law through inconsistent decisions. Fordham Law Rev 2005;73:1521-623.

90 Sornarajah M. The retreat of neo-liberalism in investment treaty arbitration. In: Rogers CA, Alford RP, eds. The future of investment arbitration. Oxford: Oxford University Press, 2009:273-96.

91 Schmitz A. Untangling the privacy paradox in arbitration. Kansas Law Rev 2006:54:1211-53.

92 International Centre for Settlement of Investment Disputes. ICSID convention, regulations and rules. general functions of the Secretariat 2006; Regulation 22.
https://icsid.worldbank.org/ICSID/StaticFiles/basicdoc/partC-chap04.htm\#r22 (accessed 12 Jan 2013).

93 International Centre for Settlement of Investment Disputes. ICSID Cases. https:/l icsid. worldbank.org/ICSID/FrontServlet?requestType=CasesRH\&actionVal= ShowHome\&pageName=Cases_Home (accessed 12 Jan 2013).

94 Cosbey A, Mann H, Peterson LE, et al. Investment and sustainable development: guide to the use and potential of international investment agreements. Winnipeg, MB: International Institute for Sustainable Development, 2004

95 United Nations Conference on Trade and Development. Investor-state disputes: prevention and alternatives to arbitration. UNCTAD series on international investment policies for development 2010. http://unctad.org/en/docs/ diaeia200911_en.pdf (accessed 23 Jan 2013).

96 United Nations Conference on Trade and Development. Latest developments in investor-State dispute settlement. IIA Monitor 2005; No. 4. http://www.unctad. org/en/docs//webiteiit20052_en.pdf (accessed 11 Oct 2012).

97 Mercurio BC. TRIPS-plus provisions in FTAs: recent trends. In: Bartels L, Ortino F, eds. Regional trade agreements and the WTO legal system. Oxford: Oxford University Press, 2006:215-37.

98 Sell SK. TRIPS was never enough: vertical forum shifting, FTAS, ACTA, and TPP. J Intellect Property Law 2011;18:447-78.

99 Handler M, Mercurio B. Intellectual property. In: Lester S, Mercurio B, eds. Bilateral and regional trade agreements. Cambridge: Cambridge University Press, 2009:308-41.

100 Haunss S. The politicisation of intellectual property: IP conflicts and social change. WIPO J 2011:3:129-38.

101 Physicians for Smoke-Free Canada. Packaging phoney intellectual property claims. June 2009. http://www.smoke-free.ca/plain-packaging/documents/2009/ packagingphoneyipclaims-june2009-a4.pdf (accessed 19 Nov 2013).

102 Mitchell A. Australia's move to the plain packaging of cigarettes and its WTO compatibility. Asian J World Trade Org Int Health Law Policy 2010;5:399-419.

103 British American Tobacco UK Limited. UK standardised packaging consultation response of British American Tobacco UK Limited. 2012. http://www.bat.com/ group/sites/uk_3mnfen.nsf/vwPagesWebLive/DO8WZC5E/\$FILE/medMD8WZC6J. pdf?openelement (accessed 22 Oct 2012).

104 Philip Morris International. Standardised tobacco packaging will harm public health and cost UK taxpayers billions: a response to the Department of Health consultation on standardised packaging of tobacco products. 2012. http://www. pmi.com/eng/tobacco_regulation/submissions/documents/submission\%20and\% 20all\%20annexes\%20\%28combined\%29.pdf (accessed 22 Oct 2012).

105 Philip Morris international. Plain packaging of tobacco products will not reduce smoking rates, and will violate New Zealand's international trade obligations. 2012. http://www.pmi.com/eng/tobacco_regulation/submissions/documents/ philip_morris_new_zealand_limited_submission_on_plain_packaging_final.pdf (accessed 22 Oct 2012).

106 Voon TS, Mitchell AD. Implications of WTO law for plain packaging of tobacco products. In: Mitchell A, Voon T, Liberman J, eds. Public health and plain packaging of cigarettes: legal issues. Cheltenham: Edward Elgar, 2012:109-36.

107 Imperial Tobacco Australia Limited. Imperial Tobacco Australia Limited Submission to the Senate Community Affairs Legislation Committee for the inquiry into the Plain Tobacco Packaging (Removing Branding from Cigarette Packs) Bill 2009. 2009. http://www.imperial-tobacco.com/files/misc/submission_on_proposals.pdf (accessed 22 Oct 2012)

108 British American Tobacco Australia. Submission on the Tobacco Plain Packaging Bill 2011. 2011. http://www.health.gov.au/internet/yourhealth/publishing.nsf/Content/ british-american-tobacco-australia\#.UIVtL_KwWk4 (accessed 22 Oct 2012).

109 McGrady B. TRIPs and trademarks: the case of tobacco. World Trade Rev 2004;3:53-82.

110 Alemanno A, Bonadio E. Do you mind my smoking? Plain packaging of cigarettes under the TRIPS Agreement. John Marshall Rev Intellect Property Law 2011;10:450-75.

111 Davidson M. The legitimacy of plain packaging under international intellectual property law: why there is no right to use a trademark under either the Paris convention or the trips agreement. In: Mitchell A, Voon T, Liberman J, eds. Public health and plain packaging of cigarettes: legal issues. Cheltenham: Edward Elgar, 2012:81-108

112 Mitchell AD, Wurzberger SM. Boxed in? Australia's plain tobacco packaging initiative and international investment law. Arbitration Int 2011;27:623-51.

113 Vadi VS. Trade mark protection, public health and international investment law: strains and paradoxes. Eur J Int Law 2009:20:773-803.

114 Agreement on trade-related aspects of intellectual property rights. Article 20. http:/ www.wto.org/english/tratop_e/trips_e/t_agm3_e.htm (accessed 19 Oct 2012).

115 Kelsey J. Tobacco industry will use offshore courts. Press Release 20 April 2012. http://www.scoop.co.nz/stories/HL1204/S00134/jane-kelsey-tobacco-industrywill-use-offshore-courts.htm (accessed 22 Sep 2012).

116 McGrady B. Revisiting TRIPS and trademarks: the case of tobacco. 2012. http://dx.doi.org/10.2139/ssin.2144269

117 Brazil-measures affecting imports of retreaded tyres - AB-2007-4-report of the appellate body. World Trade Organization 3 December 2007 (WT/DS332/AB/R). 
http://www.wto.org/english/tratop_e/dispu_e/cases_e/ds332_e.htm (accessed 19 Oct 2012)

118 Office of the United States Trade Representative. Trans-Pacific partnership intellectual property rights chapter. 2011. http://infojustice.org/download/tpp/ tpp-texts/TransPacificlP1.pdf (accessed 19 Oct 2012).

119 Porterfield MC. State practice and the (purported) obligation under customary international law to provide compensation for regulatory expropriations. N C J Int Law Commercial Regul 2011;37:159-97.

120 Brown N, Hansen C, Myers M, et al. Letter to Ron Kirk (United States Trade Representative). 2012. http://www.tobaccofreekids.org/content/what_we_do/ federal_issues/trade/20120507_ngo_letter.pdf (accessed 15 Sep 2012).

121 Action on Smoking and Health. Tobacco a big issue among TPP negotiators. 10 September 2012. http://ash.org/tobacco-a-big-issue-among-tpp-negotiators/ (accessed 15 Sep 2012)

122 Campaign for Tobacco Free Kids. Campaign for tobacco-free kids urges Trans Pacific Partnership Agreement (TPPA) negotiators to exempt tobacco products from the proposed free trade agreement. 2012. http://www. tobaccofreekids.org/content/what_we_do/federal_issues/trade/TPP.pdf (accessed 14 Sep 2012)

123 Action on Smoking and Health. 14th Round of TPP Negotiations-6-15 September 2012. 21 August 2012. http://ash.org/14th-round-of-tpp-negotiations/ (accessed 15 Sep 2012).

124 Action on Smoking and Health. United States does not table its tobacco exception at the TransPacific Partnership Negotiations. 6 July 2012. http://ash.org/ united-states-does-not-table-its-tobacco-exception-at-the-transpacific-partnershipnegotiations/ (accessed 15 Sep 2012).

125 Federal leadership on global tobacco control and prevention. Executive Order 13193, 18 January 2001

126 Department of State Cable 027439. Tobacco: guidance for U.S. diplomatic posts on health, trade and commercial issues. 14 February 1998.

127 US Government Accounting Office. Tobacco exports: USDA's foreign agricultural service lacks specific guidance for congressional restrictions on promoting tobacco. Washington, DC: US GAO, 2003. http://www.gao.gov/products/GAO-03-618 (accessed 20 Oct 2012).

128 Yang JS, Novotny TE. Policy coherence in US tobacco control: beyond FDA regulation. PLoS Med 2009:6:e1000079.

129 Office of the United States Trade Representative. Fact Sheet: TPP Tobacco Proposal. May 2012. http://www.ustr.gov/about-us/press-office/fact-sheets/2012/ may/tpp-tobacco-proposal (accessed 6 Jan 2013).

130 Office of the United States Trade Representative. TPP Tobacco Proposal. 2012. http://www.ustr.gov/about-us/press-office/factsheets/2012/may/tpp-tobaccoproposal (accessed 18 Sep 2012).

131 Harrison Institute for Public Law. Trade policy assessment. 25 June 2012. http://www. law.georgetown.edu/academics/academic-programs/dinical-programs/our-clinics/HIP/ upload/Maine-CTPC-Trade-policy-assessment-2012.pdf (accessed 17 Sep 2012).

132 JT International SA v Commonwealth of Australia/British American Tobacco Australasia Limited v The Commonwealth. High Court of Australia 2012, 5 October 2012; 43(\$409/2011. S389/2011). http://www.austlii.edu.au/au/cases/ cth/HCA/2012/43.html\#fnB420 (accessed 15 Jan 2013).
133 World Health Organization. WTO legal texts. http://www.wto.org/english/docs_e/ legal_e/legal_e.htm (accessed 27 Feb 2013).

134 United Nations Conference on Trade and Development. World Investment Report 2012. 2012. http://www.unctad-docs.org/UNCTAD-WIR2012-Full-en.pdf (accessed 3 Mar 2013).

135 Schill SW. Mulitilateralizing investment treaties through most-favored-nation clauses. Berkeley J Int Law 2009;27:496-568.

136 Brabandere ED. Co-existence, complementarity or conflict ? Interaction between preferential trade and investment agreements and bilateral investment treaties. In: Hofmann R, Tams C, Schill S, eds. Preferential trade and investment agreements: a new ordering paradigm for international investment relations? Baden-Baden: Nomos Publishers, 2013 (forthcoming).

137 Houde M-F, Yannaca-Small K. Relationships between International Investment Agreements. Working Papers on International Investment 2004, 2004/1. http://www.oecd.org/daf/inv/internationalinvestmentagreements/31784519.pdf (accessed 8 Mar 2013).

138 World Trade Organization. Dispute DS434: Australia—certain measures concerning trademarks and other plain packaging requirements applicable to tobacco products and packaging. Dispute Settlement 28 September 2012. http://www.wto.org/ english/tratop_e/dispu_e/cases_e/ds434_e.htm (accessed 10 Oct 2012).

139 World Trade Organization. Australia_certain measures concerning trademarks. Geographical indications and other plain packaging requirments applicable to tobacco products and packaging. Request for Consultations by the Dominican Republic 2012. http://www.wto.org/english/news_e/news12_e/ ds441rfc 18jul12 e.htm

140 World Trade Organization. Australia—certain measures concerning trademarks, geographical indications and other plain packaging requirements applicable to tobacco products and packaging. Request for Consultations by Honduras 2012. http://www.wto.org/english/tratop_e/dispu_e/cases_e/ds435_e.htm (accessed 17 Sep 2012)

141 World Trade Organization. Australia—certain measures concerning trademarks, geographical indications and other plain packaging requirements applicable to tobacco products and packaging. Request for Consultations by Ukraine 2012. http://www.wto.org/english/news e/news12 e/ds434rfc 13mar12_e.htm (accessed 17 Sep 2012).

142 Lalive. FTR holding SA (Switzerland) and Philip Morris Products SA (Switzerland) and Abal Hermanos SA v Oriental Republic of Uruguay. Arbitration under the Rules of the International Centre for Settlement of Investment Disputes 2010. http://www.arbitration.fr/resources/ICSID-ARB-10-7-Notice-of-arbitration.pdf (accessed 17 Sep 2012).

143 Porterfield MC, Byrnes CR. Philip Morris v. Uruguay: Will investor-State arbitration send restrictions on tobacco marketing up in smoke? 2011. http://www.iisd.org/ itn/2011/07/12/philip-morris-v-uruguay-will-investor-state-arbitration-sendrestrictions-on-tobacco-marketing-up-in-smoke/ (accessed 17 Mar 2013).

144 Gathii J. The legal status of the Doha Declaration on TRIPS and public health under the Vienna Convention on the law of treaties. Harvard I Law Technol 2002;15:291-317.

145 World Trade Organization. Understanding the WTO: settling disputes. http://www. wto.org/english/thewto_e/whatis_e/tif_e/disp1_e.htm (accessed 21 Oct 2012). 